\title{
Hubungan Pengetahuan Dengan Kejadian Merokok Pada Pelajar SMPN 1 Pariaman
}

\author{
Doppy Andika ${ }^{1}$, Oea Khairsyaf ${ }^{2}$, Dian Pertiwi ${ }^{3}$
}

\begin{abstract}
Abstrak
Indonesia menempati urutan kelima negara pengkonsumsi rokok terbanyak dan urutan ketiga negara dengan jumlah perokok terbanyak di dunia. Kelompok usia <15 tahun terjadi peningkatan jumlah perokok, peningkatan tertinggi pada kelompok usia 10-14 tahun. Salah satu faktor utama yang mempengaruhi prilaku merokok pada remaja adalah tingkat pengetahuan. Tujuan penelitian ini adalah menentukan hubungan antara pengetahuan tentang rokok dan kejadian merokok pada pelajar SMPN 1 Pariaman. Penelitian ini bersifat analitik dengan menggunakan pendekatan desain cross sectional di SMPN 1 Pariaman dari Mei 2013 hingga Januari 2014. Data yang dikumpulkan adalah data primer dengan menggunakan kuesioner kepada seluruh sampel. Uji statistik dilakukan menggunakan chisquare dengan derajat kepercayan 95\%. Hasil penelitian pada 228 orang didapatkan responden dengan tingkat pengetahuan baik sebesar $60 \%$ dan kejadian merokok sebesar $1 \%$. Analisis statistik menunjukkan bahwa terdapat hubungan antara tingkat pengetahuan tentang rokok dan kejadian merokok pada pelajar SMPN 1 Pariaman.
\end{abstract}

Kata kunci: pengetahuan, kejadian merokok, pelajar

\begin{abstract}
Indonesia ranks the fifth country with the highest cigarette consuming and the third country with the largest number of smokers in the world. The age group $<15$ years increase in the number of smokers, the highest increase in the age group 10-14 years. One of the main factors that influence smoking behavior in adolescents is knowledge level. The objective of this study was to determine the relationship between the knowledge about cigarette and the smoking incidence on students at SMPN 1 Pariaman. This research was a cross-sectional analytic study in SMPN 1 Pariaman that was conducted in Mei 2013 until January 2014. The data was collected from primary data using questionnaires to the entire sample. Statistical test was performed by chi-square with confidence level $95 \%$. The results obtained on 228 respondents with good knowledge level by $60 \%$ and the incidence of smoking by $1 \%$. The conclusion from this result show that there is a relationship between the level of knowledge about cigarette and the smoking incidence on SMPN 1 Pariaman students.
\end{abstract}

Keywords: knowledge, smoking incidence, students

Affiliasi penulis: 1. Pendidikan Dokter FK UNAND (Fakultas Kedokteran Universitas Andalas Padang), 2. Bagian Paru FK UNAND/RSUP Dr. M.Djamil, 3. Bagian Patologi Klinik FK UNAND Korespondensi: Doppy Andika, Email: doppy.a5@gmail.com Telp: 085263829933

\section{PENDAHULUAN}

Tembakau pertama kali diperkenalkan di Indonesia oleh bangsa Belanda sekitar dua abad yang lalu dan penggunaannya pertama kali oleh masyarakat
Indonesia dimulai ketika elit lokal Indonesia meniru kebiasaan merokok bangsa Belanda. Kata merokok yang berasal dari bahasa Belanda roken mulai dikenal saat itu. ${ }^{1}$

Lebih dari 3000 jurnal dan penelitian yang dipublikasikan sejak tahun 1970-an menunjukkan bahaya merokok terhadap kesehatan manusia namun ironisnya sejak tahun 1998 hingga sekarang, Indonesia menempati urutan kelima negara pengkonsumsi rokok terbanyak dan urutan ketiga 
negara dengan jumlah perokok terbanyak di dunia. World Health Organization (WHO) memprediksi bahwa tahun 2020, penyakit yang disebabkan oleh rokok akan mengakibatkan kematian sekitar 8,4 juta jiwa di seluruh dunia dan setengahnya berasal dari wilayah Asia. $^{2}$

Ada lima faktor penyebab kematian pada tahun 2020, empat diantaranya memiliki keterkaitan dengan kebiasaan merokok dan dua dari empat penyakit ini terdapat dalam ruang lingkup kesehatan paru. ${ }^{3}$

Data WHO tahun 2008 menunjukkan terdapat 1.250 milyar perokok dewasa dengan usia di atas 15 tahun di seluruh dunia dan dari jumlah tersebut sebanyak 250 juta adalah perempuan. Prevalensi perokok dewasa usia di atas 15 tahun di dunia adalah sebesar $24 \%$ dengan $40 \%$ laki-laki dan $9 \%$ perempuan. $^{2}$

Tingkat konsumsi rokok di Indonesia terus mengalami peningkatan dari tahun ke tahun. Selama kurun waktu antara tahun 1970 hingga 2000, konsumsi rokok di Indonesia meningkat tujuh kali lipat dari 33 milyar batang menjadi 217 milyar batang. Pada tahun 2008 menjadi 240 milyar batang rokok pertahun. Dengan jumlah perokok di Indonesia lebih dari 60 juta dan konsumsi rokok yang mencapai 240 milyar batang pertahun, maka dapat dikalkulasi konsumsi rokok ratarata per hari yaitu 10,95 batang. ${ }^{4}$

Penduduk Indonesia yang merokok pada usia $>15$ tahun setiap hari sebanyak 27,2\%, kadangkadang merokok sebanyak $6,1 \%$ dan mantan perokok $3,7 \%$. Jumlah perokok laki-laki sebesar 64\%, sedangkan perempuan 4,9\%. ${ }^{5}$ Pada tahun 2010, penduduk Indonesia berusia $>15$ tahun yang merokok sebesar 28,2\%, kadang-kadang merokok sebesar $6,5 \%$, dan mantan perokok sebesar 5,4\%. Jumlah perokok laki-laki sebesar $65,9 \%$ dan perempuan sebesar $4,2 \%{ }^{6}$

Provinsi Sumatera Barat menempati urutan ketujuh dari sepuluh provinsi dengan jumlah perokok terbesar di Indonesia. Persentase penduduk yang merokok mencapai 38,4\%. Persentase ini dihitung berdasarkan jumlah penduduk usia di atas 15 tahun, sedangkan untuk persentase perokok remaja di Sumatera Barat berdasarkan jumlah perokok yang berusia 15-24 tahun yaitu mencapai $19 \%{ }^{6}$
Berdasarkan data Riskesdas 2007, terjadi peningkatan jumlah perokok antara tahun 1995 hingga 2007. Pada kelompok usia 10-14 tahun terjadi peningkatan dari 0,3\% menjadi $2 \%$, usia 15-19 tahun $13,7 \%$ menjadi $18,8 \%$, dan usia $20-24$ tahun $20,3 \%$ menjadi $32,8 \%$. Berdasarkan data ini didapatkan peningkatan tertinggi pada kelompok usia 10-14 tahun yang meningkat hampir 7 kali lipat. $^{5}$

Usia pertama kali merokok berdasarkan data Riskesdas tahun 2010; 5-9 tahun 1,7\%, 10-14 tahun $17,5 \%$ dan 15-19 tahun 43,3\%. Di Sumatera Barat usia pertama kali merokok; 5-9 tahun 3,8\%, 10-14 tahun $27,7 \%$ dan $15-19$ tahun $42,1 \%$. Sumatra Barat merupakan provinsi dengan usia pertama merokok pada usia 10-14 tahun tertinggi yaitu $27,7 \%{ }^{6}$

Siswa SMP yang merupakan kelompok usia 10-14 tahun dengan peningkatan jumlah perokok tertinggi dibandingkan kelompok usia lain, yaitu hingga tujuh kali lipat. Sumatera Barat merupakan provinsi dengan usia pertama merokok 10-14 tahun tertinggi di Indonesia, yaitu $27,7 \%{ }^{6}$

Perokok biasanya mulai merokok sejak usia remaja. Salah satu pencegahan penyakit akibat rokok adalah pencegahan merokok pada usia muda. ${ }^{7}$

Penelitian ini bertujuan untuk mengetahui hubungan pengetahuan dengan kejadian merokok pada pelajar SMPN 1 Pariaman.

\section{METODE}

Penelitian ini dilakukan di SMPN 1 Pariaman dengan menggunakan pendekatan desain cross sectional pada Mei 2013 hingga Januari 2014. Populasi dalam penelitian ini adalah seluruh siswa dan siswi yang bersekolah di SMPN 1 Pariaman pada tahun 2013. Pengambilan sampel dengan teknik stratified random sampling. Jumlah seluruh pelajar SMPN 1 Pariaman adalah 363 orang. Didapatkan jumlah sampel 19 orang untuk setiap lokal dengan total 228 orang sampel. Instrumen yang dipakai adalah kuesioner khusus untuk pelajar yang digunakan oleh Global Youth Tobacco Survey (GYTS). Data diperoleh dari wawancara langsung terhadap responden dengan menggukan kuesioner yang telah disiapkan. Setelah data terkumpul, selanjutnya dilakukan pengolahan data dengan langkah-langkah; 
editing, coding, entry data dan cleaning. Data selanjutnya dianalisis dengan analisis univariat dan analisis bivariat.

\section{HASIL}

Tabel 1. Distribusi siswa perokok berdasarkan faktor orang tua yang merokok

\begin{tabular}{ccccc}
\hline \multirow{2}{*}{ Kelas } & $\begin{array}{c}\text { Siswa } \\
\text { Perokok }\end{array}$ & Ayah & Orang Tua yang Merokok \\
\cline { 3 - 5 } & & & $\begin{array}{c}\text { Ayah dan } \\
\text { lbu }\end{array}$ \\
\hline 1 & 0 & 0 & 0 & 0 \\
2 & 0 & 0 & 0 & 0 \\
3 & 2 & 2 & 0 & 0 \\
\hline Jumlah & 2 & 2 & 0 & 0 \\
\hline
\end{tabular}

Berdasarkan tabel di atas dapat dilihat bahwa dua pelajar kelas 3 yang merupakan perokok juga memiliki orang tua yang perokok.

Tabel 2. Distribusi siswa perokok berdasarkan faktor teman karib

\begin{tabular}{cccc}
\hline Kelas & Siswa & \multicolumn{2}{c}{ Teman Karib yang Merokok } \\
\cline { 3 - 4 } & Perokok & $\begin{array}{c}\text { Tidak } \\
\text { Merokok }\end{array}$ & $\begin{array}{c}\text { Semua } \\
\text { Perokok }\end{array}$ \\
\hline 1 & 0 & 0 & 0 \\
2 & 0 & 0 & 0 \\
3 & 2 & 0 & 2 \\
\hline Jumlah & 2 & 0 & 2 \\
\hline
\end{tabular}

Berdasarkan tabel di atas dapat dilihat semua teman karib dari 2 siswa perokok juga merupakan perokok

Tabel 3. Pengetahuan tentang merokok

\begin{tabular}{cccc}
\hline Kelas & Baik & Cukup & Buruk \\
\hline 1 & $71 \%$ & $7 \%$ & $22 \%$ \\
2 & $53 \%$ & $28 \%$ & $19 \%$ \\
3 & $55 \%$ & $28 \%$ & $17 \%$ \\
\hline Jumlah & $60 \%$ & $21 \%$ & $19 \%$
\end{tabular}

Berdasarkan tabel di atas dapat dilihat bahwa pelajar kelas 1 mempunyai tingkat pengetahuan paling baik tentang merokok (71\%).
Tabel 4. Persentase kejadian merokok responden

\begin{tabular}{cccccccc}
\hline \multicolumn{2}{c}{\begin{tabular}{c} 
Bukan \\
\multicolumn{2}{c}{ Perokok }
\end{tabular}} & \multicolumn{2}{c}{$\begin{array}{c}\text { Perokok } \\
\text { Ringan }\end{array}$} & \multicolumn{2}{c}{$\begin{array}{c}\text { Perokok } \\
\text { Sedang }\end{array}$} & \multicolumn{2}{c}{$\begin{array}{c}\text { Perokok } \\
\text { Berat }\end{array}$} \\
\hline $\mathbf{n}$ & $\%$ & $\mathbf{n}$ & $\%$ & $\mathbf{n}$ & $\%$ & $\mathbf{n}$ & $\%$ \\
\hline 226 & 99,2 & 1 & 0,4 & 1 & 0,4 & 0 & 0 \\
\hline
\end{tabular}

Berdasarkan tabel di atas dapat dilihat bahwa hanya $1 \%$ pelajar yang merokok, yaitu 1 orang perokok ringan dan 1 orang perokok sedang. Sisanya sebanyak 226 pelajar (99,2\%) bukan perokok.

Tabel 5. Hubungan tingkat pengetahuan tentang merokok dengan kejadian merokok

\begin{tabular}{|c|c|c|c|c|c|c|}
\hline \multirow{3}{*}{$\begin{array}{c}\text { Pengeta } \\
\text { huan }\end{array}$} & \multicolumn{4}{|c|}{ Kejadian Merokok } & & \\
\hline & \multicolumn{2}{|c|}{$\begin{array}{c}\text { Bukan } \\
\text { Perokok }\end{array}$} & \multicolumn{2}{|c|}{ Perokok } & \multicolumn{2}{|c|}{ Total } \\
\hline & $\mathbf{n}$ & $\%$ & $\mathbf{n}$ & $\%$ & $\mathbf{n}$ & $\%$ \\
\hline Baik & 136 & 100 & 0 & 0 & 136 & 100 \\
\hline Cukup & 46 & 99 & 1 & 1 & 47 & 100 \\
\hline Buruk & 44 & 99 & 1 & 1 & 45 & 100 \\
\hline Jumlah & 226 & 99,2 & 2 & 0,8 & 228 & 100 \\
\hline
\end{tabular}

Berdasarkan tabel di atas dapat dilihat responden perokok lebih kecil persentasenya dari pada responden bukan perokok. Hasil uji statistik terdapat hubungan antara tingkat pengetahuan dengan kejadian merokok $(p<0,05)$.

\section{PEMBAHASAN}

Penelitian pada pelajar SMPN 1 Pariaman mendapatkan bahwa dari 228 responden, dua orang di adalah perokok, satu orang perokok ringan dan satu orang perokok sedang. Perokok ditemukan pada pelajar kelas tiga. Pada penelitian ini didapatkan umur terendah responden mulai merokok pada usia 10-11 tahun. Menurut Mawarti tahun 2001, semakin muda usia merokok maka semakin besar kesempatan seseorang menjadi perokok berat diusia dewasa akibat efek ketagihan yang ditimbulkan oleh rokok. ${ }^{8}$

Angka di atas menggambarkan responden mulai merokok pada usia remaja, karena responden mungkin cenderung bergaul dalam lingkungan yang 
mempengaruhi timbulnya kebiasaan merokok responden. Penelitian Hansen tahun 2010, mendapatkan bahwa seseorang terutama remaja dapat menjadi perokok jika ia mempunyai teman yang juga perokok. $^{9}$

Berdasarkan hasil penelitian ini didapatkan lebih dari setengah responden berpengetahuan baik $(60 \%)$, sedangkan sisanya berpengatahuan cukup (21\%) dan berpengetahuan buruk (19\%). Secara statistik terdapat hubungan yang bermakna antara tingkat pengetahuan dengan kejadian merokok $(p=$ $0,000)$. Penelitian ini menunjukkan hasil yang sama dengan studi Kurniasih (2008) di Kota Bekasi, yang menyatakan bahwa terdapat hubungan yang bermakna antara tingkat pengetahuan dengan kebiasaan merokok. ${ }^{10}$ Hasil penelitian Afdol (2011) pada pelajar SMP di Kota Padang menyatakan adanya hubungan antara tingkat pengetahuan dengan kebiasaan merokok. ${ }^{11}$ Hal yang sama juga didapatkan penelitian Gusti dan Lalu tahun 2012 di Mataram, bahwa responden yang memiliki pengetahuan kurang tentang bahaya merokok cenderung memiliki kebiasaan merokok lebih sering. ${ }^{12}$

Dalam penelitian ini didapatkan $85 \%$ responden yang menyatakan bahwa merokok membahayakan kesehatan dan hanya $62 \%$ yang menyatakan bahwa merokok dapat mengurangi berat badan. Dampak pengetahuan terhadap rokok bagi kesehatan sangat berperan dalam prilaku seseorang. Notoadmodjo tahun 2007 mengemukakan, sebelum seseorang mengadopsi perilaku, ia harus terlebih dahulu tahu apa arti atau manfaat perilaku tersebut terhadap diri dan lingkungannya. ${ }^{13}$

\section{UCAPAN TERIMA KASIH}

Terima kasih kepada semua pihak atas bimbingan, bantuan, dan motivasi dalam penelitian ini.

\section{DAFTAR PUSTAKA}

1. Achadi A, Soeraju W, Barber S. The relevance and prospects of advancing tobacco control in Indonesia. Health Policy. 2005;72:333-49.
2. World Health Organization (WHO). Indonesia's tobacco profile. WHO report on the global tobacco epidemic. The MPOWER package. Geneva: World Health Organization; 2008.

3. Nardini S. Smoking sensation. Plymouth UK: Latimer Trend \& CO; 2008.

4. World Health Organization (WHO). Indonesia's tobacco profile. WHO report on the global tobacco epidemic. The MPOWER package. Geneva: World Health Organization; 2010.

5. Badan Penelitian dan Pengembangan Kesehatan Departemen Kesehatan Republik Indonesia. Laporan hasil riset kesehatan data nasional (RISKESDAS). Jakarta: Departemen Kesehatan Republik Indonesia; 2007.

6. Badan Penelitian dan Pengembangan Kesehatan Departemen Kesehatan Republik Indonesia. Laporan hasil riset kesehatan data nasional (RISKESDAS). Jakarta: Departemen Kesehatan Republik Indonesia; 2010.

7. Banerjee SC, Greene K. Sensation seeking and adolescent cigarette smoking. The Open Addiction Journal. 2009.

8. Mawarti. Kebijakan penanggulangan rokok. Dalam: Konferensi Nasional Promosi Kesehatan. Jakarta; 2001.

9. Hansen. Mediation designs for tobacco prevention research. 2010;68:69.

10. Kurniasih A. Faktor-faktor yang berhubungan dengan perilaku merokok pada siswa SMP Kota Bekasi tahun 2008. Jakarta: Fakultas Kesehatan Masyarakat Universitas Indonesia; 2008.

11. Afdol R. Hubungan pengetahuan dan sikap terhadap rokok dengan kebiasaan merokok siswa SMP di Kota Padang. Padang: Fakultas Kedokteran Universitas Andalas; 2011.

12. Gusti M, Lalu D. Hubungan pengetahuan remaja tentang rokok dan interaksi kelompok sebaya dengan kebiasaan pada remaja. BPTK Mataram: Dinas Kesehatan Provinsi; 2012.

13. Notoadmojo S. Promosi kesehatan dan ilmu prilaku. Jakarta: Rineka Cipta; 2007. 